\title{
COMPETENCY MODEL FOR INFORMATION SYSTEMS' SPECIALIZATION TRACK UTILIZING RIASEC AND VALUES SEARCH MODELS
}

\author{
Risty Moyo-Acerado ${ }^{1}$, Lorena W. Rabago ${ }^{2}$, and Bartolome T. Tanguilig ${ }^{3}$ \\ College of Information Technology Education, \\ Technological Institute of the Philippines, Quezon City, Philippines \\ riszty@yahoo. $\mathrm{com}^{1}$ \\ lwr823 @yahoo. $\mathrm{com}^{2}$ \\ bttanguilig_3@yahoo. $\mathrm{com}^{3}$
}

\begin{abstract}
This paper introduces the competency models for Operations Manager, User Interface Designer, and Application Developers. It will serve as a guide for Information Systems students to identify which among the three of the offered tracks would be most suited for them to pursue according to their knowledge, skills, values and interests. The Holland's RIASEC model and the Values Search model of Bronwyn and Holt were utilized to determine the most dominant interest and most dominant values of the industry computing experts. Survey assessment forms were sent to IT Operations Manager, User Interface Designer, and Application Developer. Most dominant values and interests of industry computing experts were determined as well as the knowledge and skills which are mostly required by the industry in their particular area. Based on the result of the survey, it shows that application developer and user interface designer have a closely related values. Thus a second round of a survey would be needed to come up with the most exclusive dominant values for the particular information systems specialization track.
\end{abstract}

\section{KEYWORDS}

e-learning, career assessment, profile matching, competency model

\section{INTRODUCTION}

Many factors are rarely considered in determining a student's career options which starts from choosing their college program and even in selecting elective courses. Selecting a field of specialization has never been a big deal for many students. Usually, students select those courses which they think are easy and require less paper works or projects. A fourth year irregular student said, "Honestly, I just follow my friends when taking elective courses. If that would mean they will be my classmates, then I would definitely take up those elective courses they have enrolled provided that the schedule will not give me long vacant hours..." Another student said, "When I am choosing free elective courses my friends and I choose only 1 section to have fun in every vacant hour." Moreover, students choose a college program that they think is cool, trending, or easy to pass courses to earn a degree. Sometimes, they choose tracks based from the strong influence of their parents and peers. Most often they do not completely realize the impact of their career choice in their career.

David C. Wyld et al. (Eds) : SAI, CDKP, ICAITA, NeCoM, SEAS, CMCA, ASUC, Signal - 2014 pp. 123-134, 2014. (C) CS \& IT-CSCP 2014

DOI : $10.5121 /$ csit.2014.41113 
One alumna said, "Other alumnus who didn't like IT/IS/CS but was able to finish the program was due to the fact that they felt they needed to finish the course just to earn a degree. It's just a matter of formality by all means. As long as they earn a degree and get any job. I know someone who is underemployed. She is not confident enough to apply for any programming position because she is not confident of her programming skills. "Often, students would only realize the importance of choosing the right track once they get into the real job or even from the start of sending applications to the prospective companies and desired positions where there is tight competition. Thus, many graduates end up getting jobs that are far from their field of specialization contributing to the perennial problem of job mismatching. Some may easily find jobs which seemingly are related to their field, but promotions or career growth takes longer compared to others who are competent in their field. As a result, underemployment rate increases.

According to National statistics Office of the Philippines, the underemployment rate last 2 nd and 3rd quarters of 2012 was 19.2. Underemployment means a situation in which a worker is employed but not in the desired capacity, whether in terms of compensation, hours, or level of skills and experience. [11] Moreover, [9] "Underemployment and unemployment varies a great deal depending on the major when there's a skills mismatch. With regards to compensation, [9] underemployed and unemployed graduates earn as much as 10 percent less over their careers compared to their fully employed peers. However, despite of the compensation struggle, some graduates would better be underemployed rather than unemployed.

Therefore, helping students determine the track of specialization according to their values, interests, knowledge, and skills would lead them to a more successful career. With the new curriculum of Information Systems program in Technological Institute of the Philippines (TIP), three tracks are now offered aside from elective courses it has been offering. These tracks are Application Development, Operations Management, and User interface designing.

This study focuses on constructing a competency model for Information Systems Program of TIP which would help students to decide on which track of the Information Systems Program they would consider.

\section{CONCEPTUAL FRAMEWORK}

Career counselling in Technological Institute of the Philippines was not so active yet compared with other universities until the institution implemented the student advising system. Based on the Information Systems, TIP Quezon City Self Survey Report (IS TIPQC SSR) [3] new advising scheme is intended to provide students with knowledge and guidance on academic policies, plan of study progression, career options, instructional support, and job opportunities, among others, and to monitor the attainment of relevant student outcomes." It is also intended to support students in maintaining and completing their particular plan of study on time and thus improve the institutional retention and completion rates. One motivation in conceptualizing the proposed competency model is the school's advising scheme. Having clear background of students' competencies could help faculty advisers in advising the students. The implementation of the competency model proposed by [5] focusing on a more specific engineering skills resulted to excellent performance of their students. This paper aimed to construct a model that would help to determine not just knowledge and skills of the students but as well as their values and interests.

Figure 1 represents the conceptual framework of this study. Skills and knowledge regarding the computing tools and theories from the aligned courses of Information Systems Program of TIP were identified to design a survey. While the RIASEC interest test of John Holland and value search test of Bronwyn and Holt were utilized to determine the values and interests of industry computing experts in the field related to the Information Systems three tracks. The expected 
output of this paper is the competency model of Information Systems' Specialization tracks which was based on the results of survey.

\section{INPUT}

\begin{tabular}{|l|}
\hline Data: \\
Values, interests, \\
skills and knowledge \\
Sources: \\
Industry Computing \\
Experts \\
1. Operations Managers \\
2. User Interface \\
Designers \\
3. Application \\
Developers \\
Tools: \\
1. RIASEC interest test \\
2. Value Search test \\
3. Knowledge and skills \\
checklist \\
\hline
\end{tabular}

PROCESS

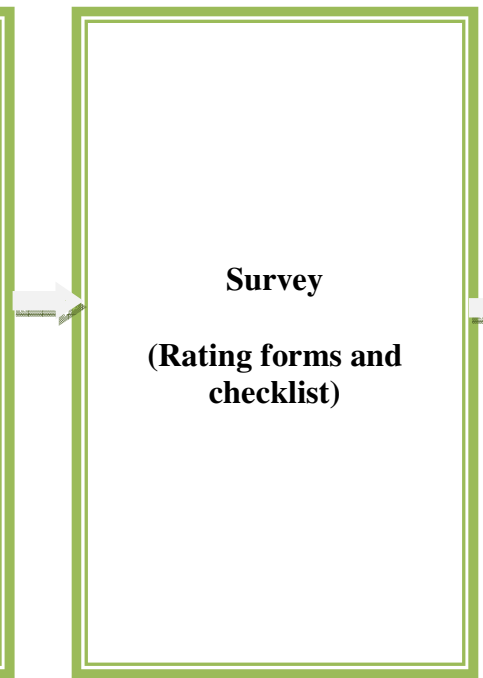

OUTPUT

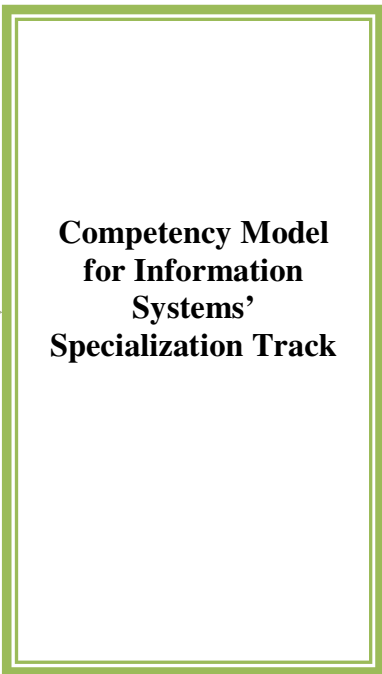

Figure 1. Conceptual Framework of the study

The Information Systems track of the College of Information Technology Education of Technological Institute of the Philippines and the aligned courses of each track are shown on the following tables below.

Table 2 shows Information Systems Track 1 - IT Operations Management, where students concentrate on business operations related to computing processes; Track 2 (table 3): User Interface Designing, where students are trained to create interfaces that organize information for users; and Track 3(table 4): Application Development, where students are trained to simplify the tasks of the end user or resolve recurring problems through process automation.

Table 1. Fundamental And Aligned Courses Of The Information Systems Program Tracks.

\begin{tabular}{|l|l|l|}
\hline $\begin{array}{l}\text { TRACK 1 } \\
\text { Operation } \\
\text { Management }\end{array}$ & $\begin{array}{l}\text { TRACK 2 } \\
\text { User Interface } \\
\text { Designing }\end{array}$ & $\begin{array}{l}\text { TRACK 3 } \\
\text { Application } \\
\text { Development }\end{array}$ \\
\hline BP(IS100) & OOP (ITE003) & DS(DS201) \\
\hline MIS(101) & OOP (ITE004) & $\begin{array}{l}\text { Deployment \& } \\
\text { Maintenance } \\
\text { (IS400) }\end{array}$ \\
\hline $\begin{array}{l}\text { Evaluation of } \\
\text { Buss. } \\
\text { Performance } \\
\text { (IS200) }\end{array}$ & $\begin{array}{l}\text { IT Infrastructure } \\
\text { (IT001) }\end{array}$ \\
\hline $\begin{array}{l}\text { PPM(IT203) } \\
\text { IT QA (IT303) }\end{array}$ & & \\
\hline SAD(IT202) & & \\
\hline DB(ITE006) & & \\
\hline $\begin{array}{l}\text { DB Oracle } \\
\text { (ITE007) }\end{array}$ & & \\
\hline
\end{tabular}


Table 1 shows fundamental courses mapped in each Information Systems track. The knowledge and skills listed on the rating form used in the survey were based from these aligned courses.

Table 2. Information Sytems Track 1 - Operations Management

\begin{tabular}{|l|l|}
\hline \multicolumn{1}{|c|}{ Course } & \multicolumn{1}{|c|}{ Description } \\
\hline IT401 & Data Mining \& warehousing \\
\hline IS403 & Business Process Management \\
\hline IS404 & Enterprise Systems \\
\hline SAP501 & Business Analytics Using SAP BW \\
\hline
\end{tabular}

Table 3. Information Sysetms Track 2 - User Interface Design

\begin{tabular}{|l|l|}
\hline Course & Description \\
\hline ITE010 & Fundamentals of HCI \\
\hline IS405 & Knowledge Management System \\
\hline IT504 & GUI System Development \\
\hline IT200 & Multimedia System Development \\
\hline
\end{tabular}

Table 4. Informations Systems Track 3 - Application Developer

\begin{tabular}{|l|l|}
\hline Course & Description \\
\hline ITE505 & Application Development \\
\hline CS305 & Computer Security \\
\hline IS503 & IT audit and control \\
\hline IS504 & IT Security \& Risk Mgt. \\
\hline
\end{tabular}

Figure 2 shows the Framework on the Assessment of Students' Competency for Information Systems Specialization Tracks. The competency model, which is the focus of this paper, is constructed based on result of the evaluations conducted from the industry computing experts. The model could then be used to determine which Information Systems track is the most appropriate for the student to pursue. The same rating tests would be sent to students to determine the student's most dominant and identified values, interest, knowledge, and skills. 


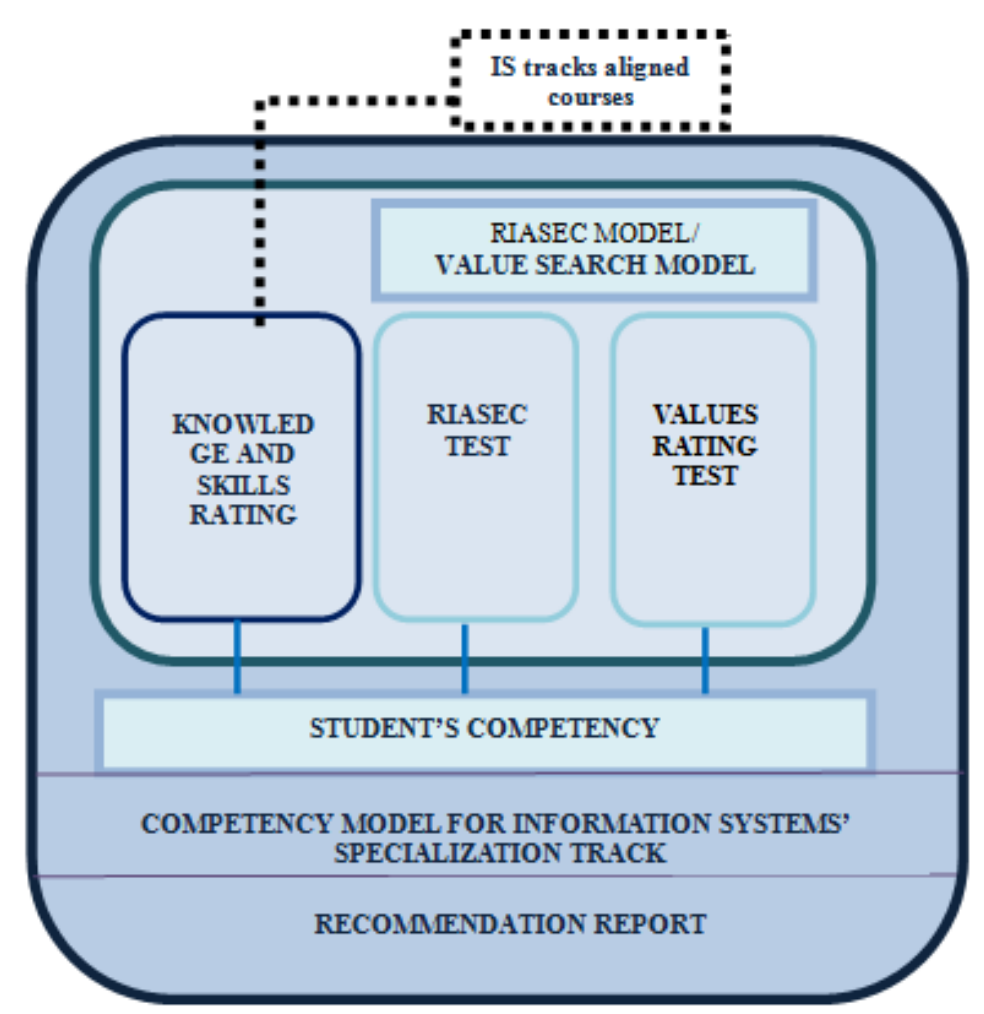

Figure 2. The Framework on the Assessment of Students' Competency for Information Systems Specialization Tracks

\section{METHODS, TECHNIQUES, MODE OF INQUIRY}

The assessment forms shown on the appendices were used to collect data from the industry computing experts particularly from the IT Operations Manager, User Interface Designer, and Application Developers.

The table shown in appendix 4 is the assessment rating form with regards to the interests expected from the aspiring operations manager, user interface designer, and application developer. This form is based from the RIASEC test designed by the Career Educational Center of University of Hawaii. [4] The RIASEC Holland Code, which stands for: R- ealistic, I-nvestigative, A-rtistic, Social, E-nterprising, C-onventional was used in this study to determine the interest of industry computing experts.

Knowledge and skills listed on the appendix 1,2, and 3 are based on the aligned courses for each track offered in the Information Systems' curriculum which would be the possible competencies acquired by the students during their training in the institution. Assessment checklist of Knowledge and skills for user interface designer composed mainly of programming languages and tools used in the courses offered in the Information Systems curriculum is shown in appendix 2. Programming languages, database systems, and other application development tools are listed on the knowledge and skills checklist for application developer as shown in appendix 3 while for the expected skills and knowledge from operations manager are shown in appendix 1 . With the revision of the Information Systems' curriculum industry experts were already considered as the program formed an advisory board composed of alumni, faculty, institution's officers, and practitioners so the initial list were all based on the updated curriculum. 
The Value Search Test found in appendix 6 was used in determining the most dominant values of the industry computing experts. The Value Search Map of Bronwyn and Holt, please refer to figure 3, were utilized to categorize the values. It has eight value categories namely, Understanding, benevolence, tradition, security, power, excitement, achievement, and selfdirection. The mapping of values can help you better understand how your values can influence and motivate your career decisions. The values test is one necessary input to best determine the Information systems specialization track of the student wherein it would help in evaluating on how well the values are integrated in the work. [6]

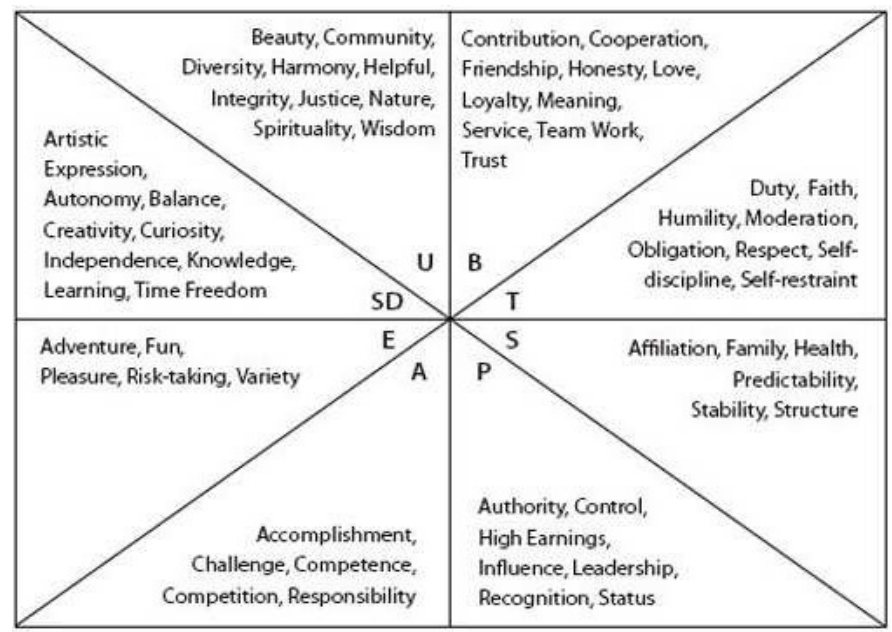

Figure 3. The Value Search Map of Bronwyn and Holt

These value search tests were sent to at least ten of the experienced operations managers, user interface designers, and application developers from the industry computing expert. At least five years of experience in the related field was considered. Determining the minimum years in service, which is five years, is based on the most common requirement of recruitment process in the computing industry.

The same assessment ratings forms will be used when the competency model is utilized in the identification of the most suitable Information Systems' track for the student to pursue.

Table 5. Profile of Respondents

\begin{tabular}{|c|c|c|}
\hline PROFESSION & $\begin{array}{c}\text { Number of } \\
\text { respondents }\end{array}$ & $\begin{array}{c}\text { Minimum of } \\
\text { years in service }\end{array}$ \\
\hline (Track1). Operations Manager & 10 & $\mathbf{5}$ \\
\hline (Track 2). User Interface Designer & 10 & $\mathbf{5}$ \\
\hline (Track 3). Application Developer & 10 & $\mathbf{5}$ \\
\hline
\end{tabular}

\section{RESULTS AND ANALYSIS}

The summation of the most required knowledge and skills of the industry computing experts were computed. The same computation was used in coming up with the top ten most dominant values. Values are then categorized using the Values Search Map [6]. Meanwhile, for the computation of the most dominant interest of the expert, each category in the assessment form was first added and categorized. Finally, results of all forms were summed up and categorized to come up with the top three most dominant interests of computing expert in each track of specialization. 
Table6. Result Of Values Survey Based On The Values Search Framework

\begin{tabular}{|r|c|c|c|}
\hline Types of Values & $\begin{array}{c}\text { Application } \\
\text { Developer }\end{array}$ & $\begin{array}{c}\text { User } \\
\text { interface } \\
\text { Designer }\end{array}$ & $\begin{array}{c}\text { Operations } \\
\text { Manager }\end{array}$ \\
\hline Openness to change: & 24 & 33 & 16 \\
\hline $\begin{array}{r}\text { self direction, excitement } \\
\text { Self-enhancement }\end{array}$ & 24 & 29 & 35 \\
\hline $\begin{array}{r}\text { achievement and power } \\
\text { Self-transcendence }\end{array}$ & 19 & 26 & 15 \\
\hline $\begin{array}{r}\text { universality and benevolence } \\
\text { Conformity }\end{array}$ & 21 & 17 & 15 \\
\hline $\begin{array}{r}\text { Traditions and security } \\
\hline\end{array}$ & & \\
\hline
\end{tabular}

Table 6 shows the result of the survey that was conducted to determine the most dominant values of experts from application developers, user interface designers, and operations manager. The user interface designers' most dominating value is the openness to change which scored 33 points. While the top values of operations manager falls under the category of self-enhancement with a score of 35 points, which means achievement and power are their highest concerns.

On the other hand, basic knowledge on programming languages and in operating systems is necessary but not required in IT operations manager. Most of the listed knowledge and skills required from application developers and user interface designers were confirmed. Please refer to table 7 and assessment rating form appendix 1,2, and 3.

Finally, with regard to the top three interests: Operations Manager has Social, Investigative, and Conventional; User Interface Design-Artistic, Social, and Enterprise; Application Developer Realistic, Investigative, and Conventional. With regard to the dominating values of the computing experts, openness to change and self enhancement are the top values of application developer which both values got the highest score of 24 points as shown in Table 8 .

Table 7. Most Required Skills And Knowledge

\begin{tabular}{|c|c|c|c|}
\hline & Operations Manager & User Interface Designer & $\begin{array}{l}\text { Application } \\
\text { Developer }\end{array}$ \\
\hline 1 & Business process & $\mathrm{HCI}$ & VB.net \\
\hline 2 & PPM & CSS & MySQL \\
\hline 3 & Accounting management & Photoshop & PHP \\
\hline 4 & $\begin{array}{c}\text { Economic and accounting } \\
\text { principles }\end{array}$ & Javascript & SqLite \\
\hline 5 & $\begin{array}{c}\text { Knowledge on Server side } \\
\text { technologies }\end{array}$ & $\begin{array}{l}\text { Understanding on difffrent } \\
\text { mobile/desktop/web } \\
\text { applications }\end{array}$ & Java \\
\hline 6 & $\begin{array}{l}\text { Knowledge on usability } \\
\text { issues }\end{array}$ & Java & Oracle \\
\hline 7 & CMS & Typography & Javascript \\
\hline 8 & Interface design & Layouting & $\begin{array}{c}\text { Design and efficiency } \\
\text { evaluation and Q.A } \\
\text { tools }\end{array}$ \\
\hline 9 & $\begin{array}{l}\text { Basic knowledge of } \\
\text { Programming languages }\end{array}$ & Flash & ASP \\
\hline 10 & $\begin{array}{l}\text { Basic knowledge of } \\
\text { operating systems }\end{array}$ & Correl draw /illustrator & Postgre \\
\hline
\end{tabular}

Table 8. The Top Three Interests Of Operations Manager, Application Developer, And User Interface Designer 


\begin{tabular}{|l|l|l|l|l|l|}
\multicolumn{2}{|c|}{ Operations Manager } & \multicolumn{2}{|c|}{ Applications Developer } & \multicolumn{2}{|c|}{ User Interface Design } \\
\hline Interest & Total & Interest & Total & Interest & Total \\
\hline S & 27 & I & 40 & S & 29 \\
\hline C & 25 & C & 31 & E & 28 \\
\hline I & 20 & R & 27 & A & 25 \\
\hline
\end{tabular}

Top three interests of operations manager as shown on table 8 are Social, Conventional, and Investigative. While for the applications developer top three interests are investigative, conventional, and realistic. User interface designer's top three interests are, social, enterprise, and artistic.

\section{COMPETENCY MODELS FOR INFORMATION SYSTEMS SPECIALIZATION TRACKS}

The most dominant values of operations manager is under the category of self-enhancement. Among the three tracks it got the highest score of 35 which is $13 \%$ higher than that of user interface designer and $8 \%$ higher than the application developer as shown in table

Table 9. Operations Manager Competency Model

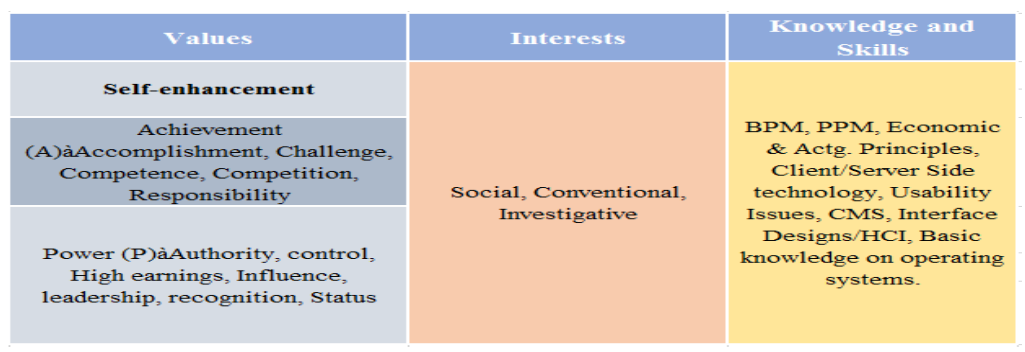

Table 10. Applications Developer Competency Model

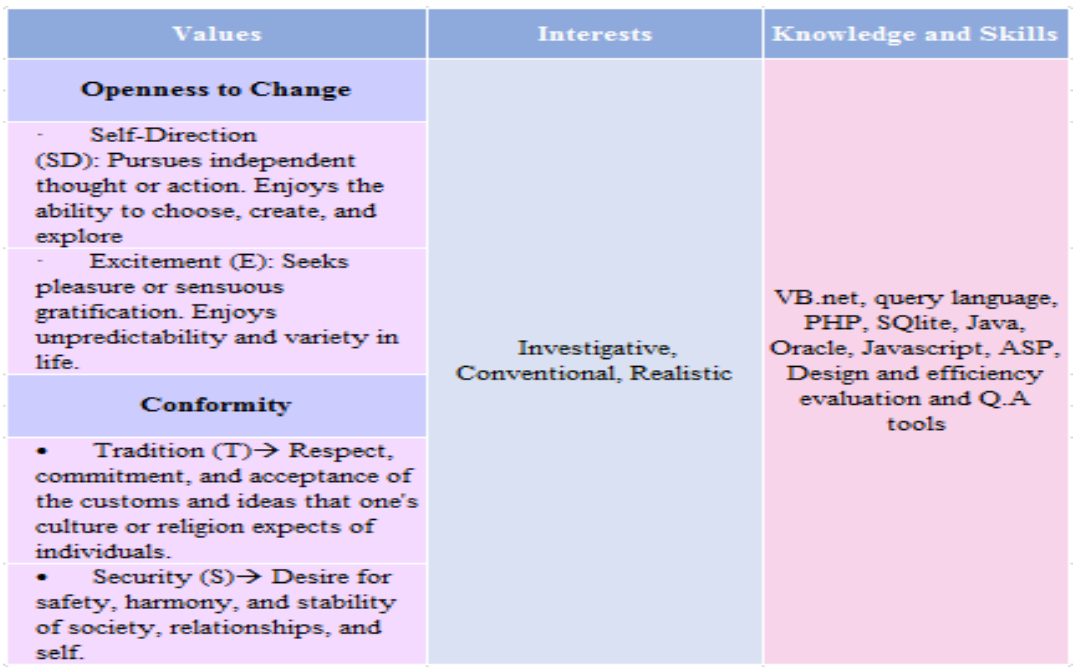

Application developer's most dominant values are under the categories of openness to change and self-enhancement which got the score of 24 each respectively. However, the conformity category 
got the highest score of 21 compared with the scores of operations manager, and user interface designer.

Table 11. User Interface Designer Competency Model

\begin{tabular}{|c|c|c|}
\hline Values & Interests & Knowledge and Skills \\
\hline Self-transcendence & \multirow{5}{*}{ Social, Enterprise, Artistic } & \multirow{5}{*}{$\begin{array}{l}\text { HCI, CSS, Photoshop, } \\
\text { JavaScript, } \\
\text { Understanding on } \\
\text { difffrent } \\
\text { mobile/desktop/web } \\
\text { applications,Java, } \\
\text { Typography, layouting, } \\
\text { Flash }\end{array}$} \\
\hline $\begin{array}{l}\text { Universality }(U) \text { : Understanding, } \\
\text { appreciation, tolerance, and } \\
\text { protection for the welfare of people } \\
\text { and nature. } \\
\text { Benevolence (B): Concern for the } \\
\text { protection and enhancement of the } \\
\text { welfare of people with whom one is in } \\
\text { frequent contact. }\end{array}$ & & \\
\hline Openness to Change & & \\
\hline $\begin{array}{l}\text { Self-Direction (SD): Pursues } \\
\text { independent thought or action. } \\
\text { Enjoys the ability to choose, create, } \\
\text { and explore }\end{array}$ & & \\
\hline $\begin{array}{l}\text { Excitement }(E) \text { : Seeks pleasure or } \\
\text { sensuous gratification. Enjoys } \\
\text { unpredictability and variety in life. }\end{array}$ & & \\
\hline
\end{tabular}

The most dominant values of user interface designer falls under the category of openness to change. While the values under self- transcendence got higher scores compared with other tracks.

\section{CONLCUSION AND FUTURE WORKS}

Based on the result of the survey, it shows that application developer and user interface designer have closely related values. Thus, another round of conducting a survey would be needed to come up with the most exclusive dominant values for the particular information systems specialization track.

For future works, the competency models can be implemented to a computer application that will cater the processing of the identification of Information Systems track to be recommended to the information systems students according to their competency.

\section{REFERENCES}

[1] Philippines National Statistics Office Website.www. Census.gov.ph/statistics/survey/labor-force. Retrieved on October 18, 2013.

[2] TIP Quezon City IS ABET SSR. Technological Institute of the Philippines. Quezon City, Philippines

[3] Singh, Raghav. Generation U. Too Many Underemployed CollegeGrads. http://www.ere.net/2013/07/19/generation-u-too-many-underemployed-college-grads/

[4] Quiang, Li and Shiyan, Wen. A competency Model for Civil Engineering

[5] Career and Technical Education Center. www.hawaii.edu/cte/publications/RIASEC.pdf

[6] Bronwyn, Llewellyn and Holt, Robin. Values test. http://www.netplaces.com/career-tests/values-andyour-career/values-test.htm. retrieved on october 16, 2013. 


\section{APPENDICES}

\section{APPENDIX 1}

Assessment Rating Form For Operations Manager - Knowledge And Skills

\begin{tabular}{|c|c|c|}
\hline \multicolumn{3}{|l|}{$\begin{array}{l}\text { CHECK THE KNOWLEDGESKILLS WHICH ARE } \\
\text { REOUIRED FOR USER OPERATIONS MANAGER }\end{array}$} \\
\hline KNOWLEDGE \& SKILLS & Required & \\
\hline & $\mathbf{Y}$ & $\mathbf{N}$ \\
\hline Management (people, time, resources) & & \\
\hline Colour skills and design knowledge & & \\
\hline Expert on different operating systems & & \\
\hline Microsoft office applications & & \\
\hline Coding languages: HTML, XHTML css & & \\
\hline $\begin{array}{l}\text { Basic knowledge: PHP, MySQL, JavaScript, JQuery, } \\
\text { AJAX }\end{array}$ & & \\
\hline Content Management Systems(CMS) & & \\
\hline $\begin{array}{l}\text { Streaming formats: flash, QuickTime, Windows } \\
\text { media, }\end{array}$ & & \\
\hline Business Process & & \\
\hline In-depth knowledge of usability issues & & \\
\hline Project and planning management & & \\
\hline Economic and acoounting principles & & \\
\hline Understanding of server side technologies & & \\
\hline Understanding of Interface design & & \\
\hline $\begin{array}{l}\text { Other Application Or Tools, Skills,knowiedge (Pls. If } \\
\text { Blank Cells Below) }\end{array}$ & cate: On & \\
\hline
\end{tabular}

\section{APPENDIX 2}

Assessment Rating Form For User Interface Designer - Knowledge And Skills

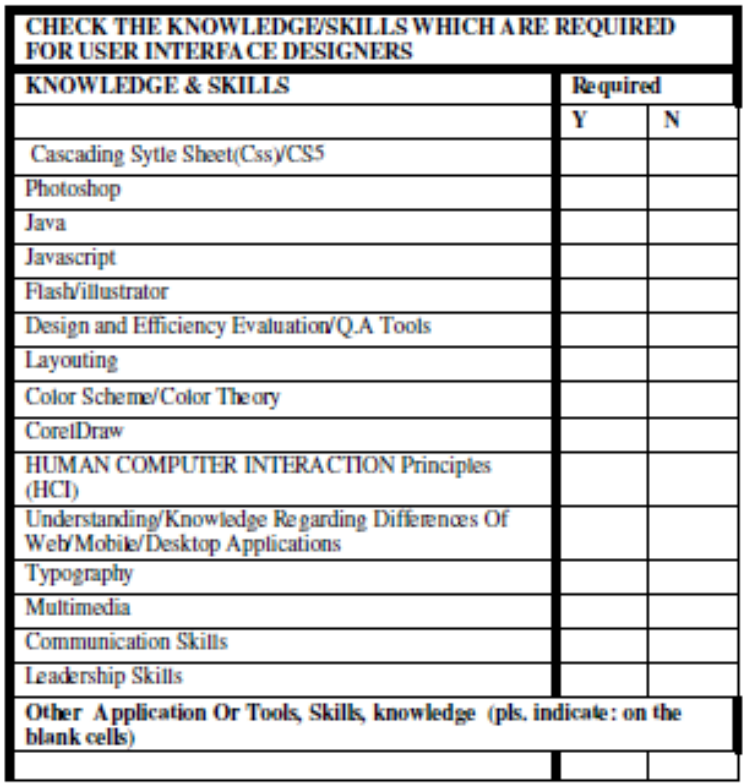


APPENDIX 3

Assessment Rating Form For Application Developer -Knowledge And Skills

\begin{tabular}{|c|c|c|}
\hline \multicolumn{3}{|c|}{$\begin{array}{l}\text { CHECK THE KNOWLEDGEJSKILLS WHICH } \\
\text { ARE REQUIRED FOR ANAPPLICATION } \\
\text { DEVELOPER }\end{array}$} \\
\hline \multirow[t]{2}{*}{ KNOWLEDGE \& SKILLLS } & \multicolumn{2}{|c|}{ Required } \\
\hline & $\mathbf{Y}$ & $\mathbf{N}$ \\
\hline \multicolumn{3}{|l|}{ VB.net } \\
\hline \multicolumn{3}{|l|}{ Sqlite } \\
\hline \multicolumn{3}{|l|}{ Oracle } \\
\hline \multicolumn{3}{|l|}{ MySQL } \\
\hline \multicolumn{3}{|l|}{ Postgre } \\
\hline \multicolumn{3}{|l|}{ PHP } \\
\hline \multicolumn{3}{|l|}{ MSSQL } \\
\hline \multicolumn{3}{|l|}{ Java } \\
\hline \multicolumn{3}{|l|}{ ASP } \\
\hline \multicolumn{3}{|l|}{ JavaScript } \\
\hline \multicolumn{3}{|l|}{$\begin{array}{l}\text { Design and Efficiency } \\
\text { EvaluationVQ.A Tools }\end{array}$} \\
\hline \multicolumn{3}{|c|}{$\begin{array}{l}\text { Other Application Or Tonls, Skills,know ledge (Pls. } \\
\text { Indicate: On The Blank Cells Below) }\end{array}$} \\
\hline
\end{tabular}

APPENDIX 4

Interests Assessment Rating Form For Operations Manager, User Interface Designer, And Application Developer

\begin{tabular}{|c|c|c|c|c|c|c|c|}
\hline Llilituvarimas - - - & S & & & 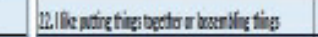 & & & \\
\hline 21 thetutoparits & & & & 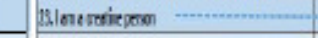 & & 0 & \\
\hline 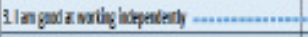 & & $\ldots$ & & 121panariw x kad - & & & \\
\hline CIBetuvathien & & & & 15.lbentully $x$ aping & 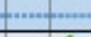 & & 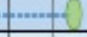 \\
\hline 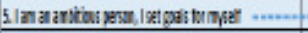 & & & $\cdots$ & 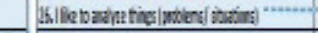 & 2 & & \\
\hline 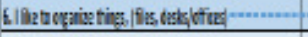 & & + & & 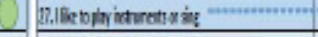 & & +0 & \\
\hline 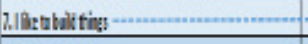 & 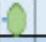 & & & 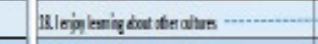 & & 0 & \\
\hline 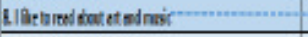 & & Q & & 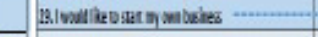 & & & 0 \\
\hline 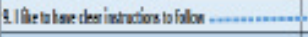 & & & & 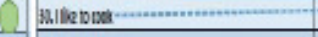 & -1) & & \\
\hline 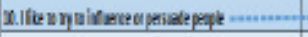 & & $m$ & & 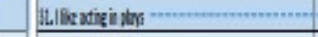 & & & \\
\hline L.Ilen wangirats & $\ldots$ & C & & Relone notisjecen ….... & - & & \\
\hline 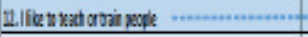 & $\ldots$ & ... & & 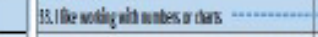 & 2 & & \\
\hline 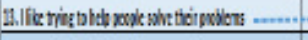 & $\ldots$ & $\ldots$ & & 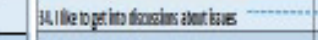 & & & \\
\hline 4. life to teitcon is sires. & S & & & 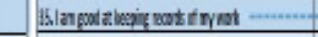 & & & U \\
\hline 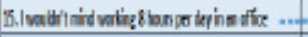 & & & & SWlleblai & & & -0 \\
\hline 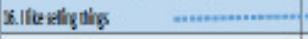 & & & & 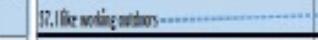 & -1 & & \\
\hline IT. leviop oxtie vith - - & & 0 & & 18. Inullite ow hathelle ". & & & \\
\hline 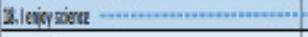 & & 1 & & 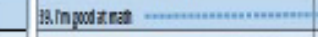 & 0 & & \\
\hline 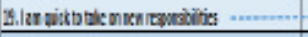 & & & & 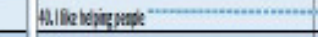 & & & \\
\hline 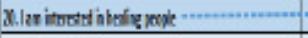 & & $=$ & & Halliketotin $\cdots$ & & 0 & \\
\hline 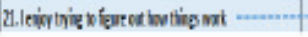 & $-\cdots$ & 0 & & 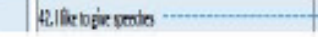 & & & 0 \\
\hline
\end{tabular}




\section{APPENDIX 5}

Value Assessment Rating Form For Operations Manager, User Interface Designer, And Application Developer

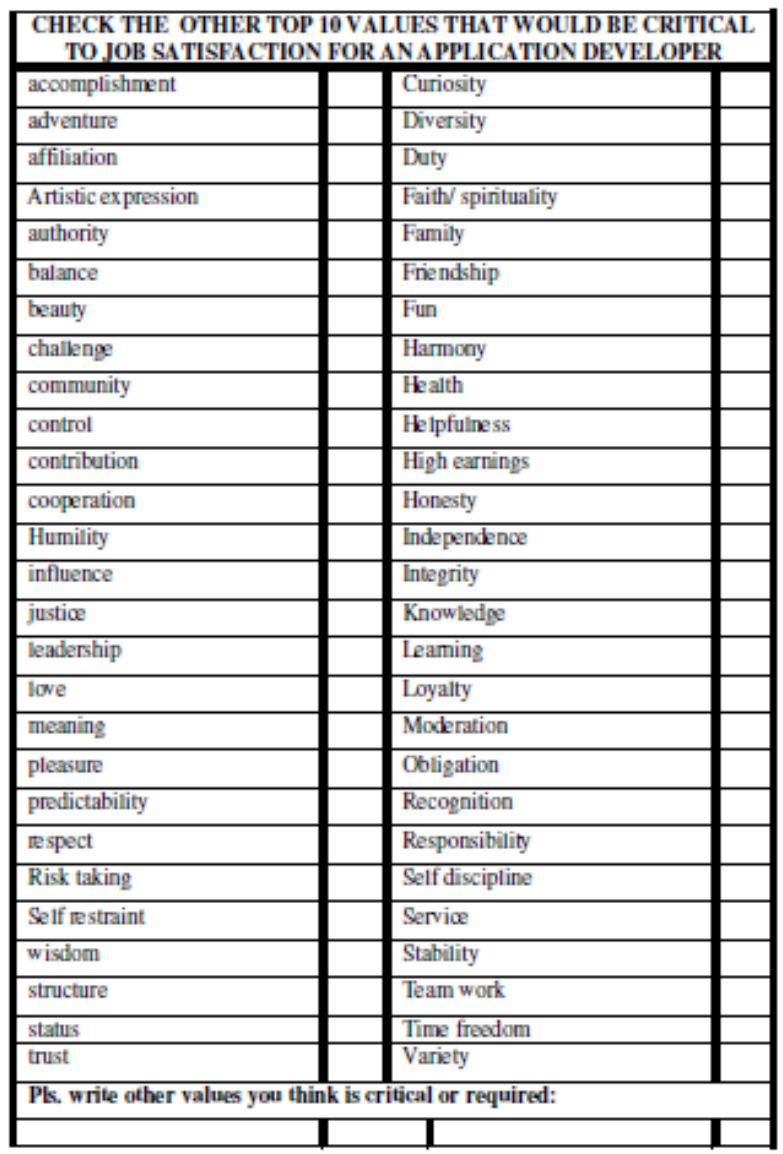

